Letters to the Editor

\title{
"Between-Program Injection" Technique as a Versatile Tool for Gradient Elution
}

\author{
Hiroshi Nakamura*, Tadao Konishi** and Masafumi Kamada** \\ *Department of Analytical Chemistry, Faculty of Pharmaceutical Sciences, The University of Tokyo, \\ Hongo, Tokyo 113 \\ ** Kanto Chemical Co., Inc., 3-2-8, Nihonbashi Honcho, Tokyo 103
}

\begin{abstract}
Keywords Gradient elution, injection technique, high performance liquid chromatography, reversed-phase, aromatic compound, protein
\end{abstract}

Gradient elution is a wide-spread technique for separation of multiple components with large differences in their capacity factors. Many gradient devices for HPLC are commercially available. ${ }^{1-3}$ Although great efforts have been made to achieve ideal gradient elution curves ${ }^{4,5}$, they seem to be mainly concentrated on the improvement of pumping and mixing systems. ${ }^{6-8}$ On the other hand, a problem of time lag between programmed curve and actual one still remains unsolved; this is caused by large void volumes of the mixer and tubing connectors. However, it is impossible to eliminate such time lags only by improvement of instruments. In this paper, a simple and useful technique to minimize the problematic time lag is presented: A sample held in advance in the sample loop was introduced to the column at a proper interval after the start of a gradient program. By using this new technique, chromatograms were remarkably simplified without undesirable long pause in front of the first sample peak.

\section{Experimental}

\section{Reagents}

Acetone and acetonitrile of HPLC grade (CicaMerck HLC-SOL, Kanto Chemical Co., Inc., Tokyo, Japan) were used. Water was purified by the Milli-Q system (Millipore Corp., Bedford, MA, U.S.A.). Trifluoroacetic acid (TFA) was purchased from E. Merck (Darmstadt, F.R.G.). Resorcinol, phenol, benzene, butyl benzoate, hexyl benzoate and octyl benzoate were obtained from Kanto Chemical. Uracil was purchased from Tokyo Kasei Kogyo Co., Ltd. (Tokyo, Japan). Ribonuclease from bovine pancreas (Boehringer-Mannheim, F.R.G.), insulin from bovine pancreas (Sigma Chemical Co., St. Louis, MO, U.S.A.), lysozyme from hen's egg white and trypsin inhibitor from soybean ( $E$. Merck) were used without further purification.

\section{Instruments}

The HPLC system used consisted of an L-6000 intelligent pump and an L-6200 intelligent pump (Hitachi Ltd., Tokyo, Japan) equipped with a highpressure gradient programmer controlled by an internal CRT computer, a Hitachi L-4000 UV detector and a Hitachi D-2500 data processor. A reversed-phase LiChroCART LiChrospher RP-Select B column $(5 \mu \mathrm{m}$, $4.0 \mathrm{~mm}$ i.d. $\times 250 \mathrm{~mm}$, Kanto Chemical) and a LiChroCART guard column LiChrosorb RP-Select B $(5 \mu \mathrm{m}$, $4.0 \mathrm{~mm}$ i.d. $\times 4 \mathrm{~mm}$, E. Merck) were used.

\section{Results and Discussion}

Profiles of time lag between programmed and actual gradient curves

The time lag between programmed and actual gradient curves was examined by using acetone as a

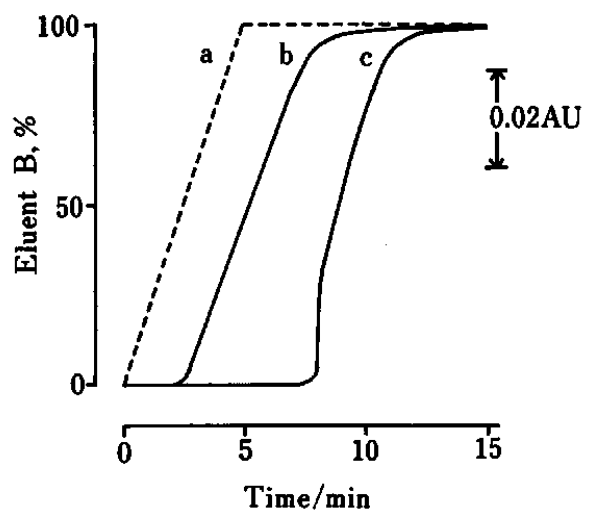

Fig. 1 Time lag between programmed and actual gradient elution. Eluent A, 0.5\% acetone; Eluent B, 5.0\% acetone; flow rate, $1.0 \mathrm{ml} / \mathrm{min}$; detection, UV $315 \mathrm{~nm}$; gradient profile: a, programmed profile; $b$, without column; $c$, with column (LiChroCART LiChrospher RP-Select B, $5 \mu \mathrm{m}, 4.0 \mathrm{~mm}$ i.d. $\times 250 \mathrm{~mm}$ ); column temperature, ambient. 


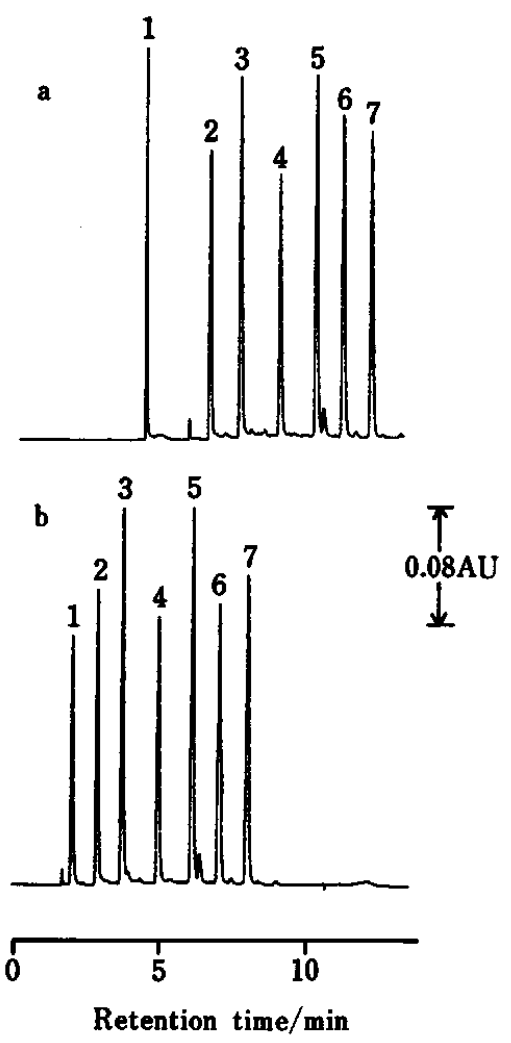

Fig. 2 Separation profiles of aromatic compounds by gradient elution. Eluent A, water; Eluent B, acetonitrile; linear gradient, from 0\% Eluent B to $100 \%$ Eluent B in $5 \mathrm{~min}$; column and column temperature, the same as Fig. 1; detection, UV $254 \mathrm{~nm}$. Peak identities: 1, uracil $(0.044 \mathrm{mg} / \mathrm{ml}), 2$, resorcinol $(1.25 \mathrm{mg} / \mathrm{ml}), 3$, phenol $(1.25 \mathrm{mg} / \mathrm{ml}), 4$, benzene $(1.25 \mathrm{mg} / \mathrm{ml}), 5$, butyl benzoate $(1.25 \mathrm{mg} / \mathrm{ml}), 6$, hexyl benzoate $(1.25 \mathrm{mg} / \mathrm{ml}), 7$, octyl benzoate $(1.25 \mathrm{mg} / \mathrm{ml})$; injection volume, $5 \mu$ l. Sample injection: a, sample mixture was injected at the same time as the program start; $b$, injected 4 min after the start.

UV absorbing marker. As shown in Fig. 1, there is a rather large time lag between programmed (a) and actual gradient profiles without column (b), or with column (c). The time lag was about $2.5 \mathrm{~min}$ in the absence of the column, suggesting the presence of $2.5 \mathrm{ml}$ of the void volume in the system. When the column was connected, it was estimated to be $7 \mathrm{~min}$ by extrapolation of the straight part of the curve, though a rapid increase of UV absorption was actually observed after $8 \mathrm{~min}$ due to the retention of acetone to the reversed-phase column.

\section{Gradient elution of aromatic compounds and proteins}

Seven aromatic compounds were subjected to the gradient elution on the reversed-phase column using acetonitrile-water mobile phase. Figure $2 a$ is a profile with the usual gradient elution, in which the sample was injected at the same time as the start of the program. Figure $2 b$ is the result of "Between-Program Injection" in which sample was injected $4 \mathrm{~min}$ after the start of the

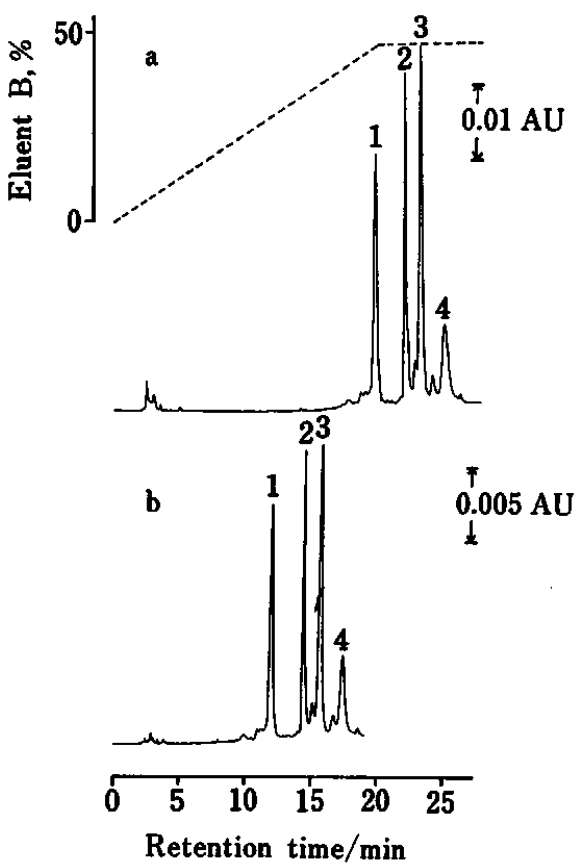

Fig. 3 Separation profiles of proteins by gradient elution. Eluent $A$, acetonitrile-water $(10: 90, v / v)$ containing $0.1 \%$ TFA; Eluent B, acetonitrile-water $(95: 5, v / v)$ containing $0.1 \%$ TFA; detection, UV $280 \mathrm{~nm}$; column and column temperature, the same as Fig. 1. Peak identities: 1, ribonuclease $(2.68 \mathrm{mg} / \mathrm{ml}), 2$, insulin $(1.91 \mathrm{mg} / \mathrm{ml}), 3$, lysozyme $(0.67 \mathrm{mg} / \mathrm{ml}), 4$, trypsin inhibitor $(2.68 \mathrm{mg} / \mathrm{ml})$. Sample injection: a, sample mixture $(10 \mu \mathrm{l})$ was injected at the same time as the program start; $b$, sample mixture $(5 \mu l)$ was injected $7 \mathrm{~min}$ after the start.

Table 1 Reproducibilities of retention times obtained by "Between-Program Injection" technique

\begin{tabular}{lc}
\hline \multicolumn{1}{c}{ Sample } & R.S.D., \% \\
\hline Aromatic compound & \\
Uracil & 0.37 \\
Resorcinol & 0.39 \\
Phenol & 0.49 \\
Benzene & 0.42 \\
Butyl benzoate & 0.43 \\
Hexyl benzoate & 0.43 \\
Octyl benzoate & 0.39 \\
& \\
Protein & \\
Ribonuclease & 4.92 \\
Insulin & 4.42 \\
Lysozyme & 3.72 \\
Trypsin inhibitor & 6.92 \\
\hline
\end{tabular}

$n=7$ (aromatic compound), $n=6$ (protein). HPLC conditions are the same as in Fig. 2b (aromatic compound) and Fig. 3b (protein).

program. This technique was applied to the separation of proteins on the column with $0.1 \%$ TFA-acetonitrile mobile phase (Fig. 3). In this case, proteins were 
injected $7 \mathrm{~min}$ after the start of the program. As illustrated in Fig. 3b, the chromatogram was remarkably improved without the unnecessary region in front of the protein peaks, with resolution equal to that by the usual gradient elution (Fig. 3a). The reproducibilities of retention times obtained by the present "BetweenProgram Injection" technique are summarized in Table 1. Although relative standard deviations (RSD) of aromatic compounds were less than $0.5 \%$, those of proteins were rather large (4-7\%). The large deviations observed in the protein separation are considered to be due to slight differences of TFA concentration in the eluent, which affects the net charges of proteins to alter their affinities to the reversed-phase column. As demonstrated above, the "Between-Program Injection" technique proved to be useful for obtaining goodlooking chromatograms in the gradient elution, especially that of proteins, and for saving the recording paper as well.

\section{References}

1. J. W. Dolan, J. R. Gant and L. R. Snyder, J. Chromatogr., 165, 31 (1979).

2. P. Jandera and J. Churákek, J. Chromatogr., 192, 19 (1980).

3. P. Jandera and M. Špacek, J. Chromatogr., 366, 107 (1986).

4. M. A. Quarry, R. L. Grob and L. R. Snyder, $J$. Chromatogr., 285, 1 (1984).

5. M. A. Quarry, R. L. Grob and L. R. Snyder, J. Chromatogr., 285, 19 (1984).

6. M. Kamiński, J. Klawiter and J. S. Kowalczyk, J. Chromatogr., 176, 171 (1979).

7. T. Takeuchi and D. Ishii, J. Chromatogr., 253, 41 (1982).

8. T. Hoshino, J. Chromatogr., 316, 415 (1984).

(Received September 30, 1988) (Accepted October 5, 1988) 